\title{
THE INCIDENCE OF TWINS IN CEREBRAL PALSY AND MENTAL RETARDATION
}

\author{
BY
}

\author{
R. S. ILLINGWORTH and GRACE E. WOODS \\ From the Department of Child Health, The University of Sheffield, and the Royal Hospital for Sick Children, Bristol
}

(RECEIVED FOR PUBLICATION OCTOBER 15, 1959)

There is evidence that there is a higher incidence of mental retardation and of cerebral palsy among children born from a multiple pregnancy than among singletons. Asher and Schonell (1950) found that $5.4 \%$ of their 400 cases of cerebral palsy were members of twins. Greenspan and Deaver (1953) found that $7 \%$ of their 94 cases resulted from multiple pregnancies. The corresponding figure in Shyh-Jong's series of 301 cases (Yue, Shyh-Jong, 1955), was $9.0 \%$.

Looft (1931) found a higher incidence of imbeciles in a group of 64 twins than one finds in the normal population, and among siblings and parents of backward children there were more twins than among normal children. Rosanoff and InmanKane (1933) studied 234 pairs of mentally defective twins. They found a higher incidence of mental defects in twins than in singletons. McKinney, Dunphy and Pessin (1958) and Drillien (1959) made similar observations. The latter, in her follow-up of the intelligence quotient of premature babies, found that twins scored less than singletons.

It is not easy to interpret these observations, on account of the higher incidence of cerebral palsy with or without mental retardation, and of mental retardation alone, in prematurely born children, and the high incidence of prematurity in multiple pregnancy.

One could not say, therefore, whether the high incidence of twins in children with mental retardation or with cerebral palsy is merely due to the high incidence of prematurity associated with multiple pregnancy. We therefore set out to elucidate the matter.

An analysis of mentally retarded children or children with cerebral palsy seen at the Children's Hospital, Sheffield did not provide sufficient material for satisfactory statistical conclusions to be made. Accordingly, Dr. Grace Woods of Bristol was asked to cooperate by supplying figures from her large series seen at the Cerebral Palsy Assessment Clinic at the Bristol Children's Hospital (in the case of cerebral palsy), and at a mental deficiency hospital, a mental health clinic and an occupation centre. The Department of Medical Statistics, at the University of Sheffield, analysed the figures.

We made no attempt to distinguish identical from non-identical twins owing to the difficulty of distinguishing these without such accurate methods as the study of blood groups.

\section{The Statistical Problem}

The Table sets out the basic data, from which it can be seen that of 729 mentally retarded children, including mongols, $153(20.9 \%)$ were prematurely born, as compared with 234 of 651 children with cerebral palsy $(35.9 \%)$; of 729 mentally retarded children including mongols, 28 were members of

TABLE

INCIDENCE OF PREMATURITY AND TWINS IN MENTAL RETARDATION AND CEREBRAL PALSY

\begin{tabular}{|c|c|c|c|c|c|c|c|c|c|}
\hline & \multicolumn{3}{|c|}{$\begin{array}{l}\text { Mental Retardation excluding } \\
\text { Mongolism or Cerebral Palsy }\end{array}$} & \multicolumn{3}{|c|}{ Mongols } & \multicolumn{3}{|c|}{ Cerebral Palsy } \\
\hline & Sheffield & Bristol & Total & Sheffield & Bristol & Total & Sheffield & Bristol & Total \\
\hline $\begin{array}{l}\text { Premature singletons } \\
\text { Full term singletons } \\
\text { Premature twins } \\
\text { Full term twins }\end{array}$ & $\begin{array}{r}68 \\
274 \\
8 \\
3\end{array}$ & $\begin{array}{r}40 \\
188 \\
6 \\
6\end{array}$ & $\begin{array}{r}108 \\
462 \\
14^{*} \\
9 \dagger\end{array}$ & $\begin{array}{l}16 \\
46 \\
2 \ddagger \\
1\end{array}$ & $\begin{array}{r}11 \\
58 \\
2 \\
0\end{array}$ & $\begin{array}{r}27 \\
104 \\
4 \\
1\end{array}$ & $\begin{array}{r}76 \\
155 \\
12 \\
9\end{array}$ & $\begin{array}{r}115 \\
250 \\
31 \\
3\end{array}$ & $\begin{array}{c}191 \\
405 \\
43 \S \\
12\end{array}$ \\
\hline Total & 353 & 240 & 593 & 65 & 71 & 136 & 252 & 399 & 651 \\
\hline
\end{tabular}

* Four premature twins were siblings.

+ Six full term twins were siblings.

\pm Two premature twins were siblings.

$\S$ Four premature twins were siblings. 
twins $(3.8 \%)$, as compared with 55 of 651 cases of cerebral palsy $(8 \cdot 4 \%)$.

Our studies showed that of 375 consecutive premature births in two Sheffield hospitals, 44 children $(11.2 \%)$ were members of twins (Dr. Ronald Gordon kindly supplied figures for the City General Hospital, Sheffield. The remaining figures were from the Jessop Hospital for Women), and of 252 consecutive twins in the two Sheffield hospitals, $145(57 \cdot 7 \%)$ were 'premature', weighing $5 \frac{1}{2} \mathrm{lb} .(2,500$ g.) or less. The incidence of twins in the normal population was taken as $1.2 \%$ and the incidence of prematurity as $6.0 \%$.

Results of Statistical Analysis. The high incidence of twins in cerebral palsy is not merely a reflection of the high incidence of prematurity.

The high incidence of twins in mentally retarded children may well be due merely to the high incidence of prematurity.

\section{Discussion}

The reason for the high incidence of multiple pregnancy in the history of children with cerebral palsy is unknown. The factors concerned may be partly genetic and partly obstetrical, multiple preg- nancies being associated with a high incidence of abnormal presentations and deliveries. The evidence for a genetic factor in some cases of cerebral palsy has been set out elsewhere (Illingworth, 1958).

\section{Summary}

We set out to determine whether the high incidence of twins in children with cerebral palsy and with mental retardation without cerebral palsy is merely due to the high incidence of prematurity associated with multiple pregnancy. Statistical analysis has shown that in the case of cerebral palsy the high incidence of twins is not explained by the high incidence of prematurity which is known to be related to cerebral palsy. In the case of mentally retarded children without cerebral palsy the high incidence of twins may well be merely related to the high incidence of prematurity known to be a factor in mental retardation.

Of 729 mentally retarded children without cerebral palsy, $20.9 \%$ were prematurely born and the incidence of twins was $3 \cdot 8 \%$. Of 651 children with cerebral palsy, $35.9 \%$ were prematurely born, and $8 \cdot 4 \%$ were twins.

\section{Statistical Addendum}

BY

\section{G. H. JOWETT and WENDY M. WRIGHT \\ From the Department of Statistics, University of Sheffield}

Estimates of the main probabilities required for a test of significance on the data in Table 1 are given in Table 3. These have been deduced from the facts given in Table 2 using the method of weighted least squares to resolve the inconsistencies of the latter. In doing this, the following points have been borne in mind:

(1) The first two figures of Table 2 , though rough,
TABLE 2

INCIDENCE DATA FOR PREMATURITY AND MULTIPLICITY

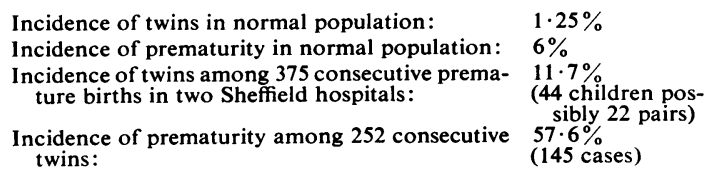

TABLE 1

DISTRIBUTION OF CASES ACCORDING TO PREMATURE AND MULTIPLE STATUS FOR DIFFERENT CONDITIONS (BRISTOL AND SHEFFIELD)

\begin{tabular}{|c|c|c|c|c|c|c|}
\hline - & & $\begin{array}{l}\text { Premature } \\
\text { Singletons }\end{array}$ & $\begin{array}{l}\text { Full term } \\
\text { Singletons }\end{array}$ & $\begin{array}{l}\text { Premature } \\
\text { Twins }\end{array}$ & $\begin{array}{l}\text { Full term } \\
\text { Twins }\end{array}$ & Total \\
\hline \multirow[t]{2}{*}{ Cerebral palsy } & $\begin{array}{l}\text { Sheffield } \\
\text { Bristol }\end{array}$ & $\begin{array}{r}76 \\
115\end{array}$ & $\begin{array}{l}155 \\
250\end{array}$ & $\begin{array}{l}12 \\
31\end{array}$ & $\begin{array}{l}9 \\
3\end{array}$ & $\begin{array}{l}252 \\
399\end{array}$ \\
\hline & Total & $191(29 \cdot 3 \%)$ & $405(62 \cdot 2 \%)$ & $43(6 \cdot 6 \%)$ & $12(1 \cdot 8 \%)$ & 651 \\
\hline \multirow[t]{2}{*}{ Simple mental defectives } & $\begin{array}{l}\text { Sheffield } \\
\text { Bristol }\end{array}$ & $\begin{array}{l}68 \\
40\end{array}$ & $\begin{array}{l}274 \\
188\end{array}$ & $\begin{array}{l}8 \\
6\end{array}$ & $\begin{array}{l}3 \\
6\end{array}$ & $\begin{array}{l}353 \\
240\end{array}$ \\
\hline & Total & $108(18 \cdot 2 \%)$ & $462(77 \cdot 9 \%)$ & $14(2.4 \%)$ & $9(1.5 \%)$ & 593 \\
\hline \multirow[t]{2}{*}{ Mongol idiots } & $\begin{array}{l}\text { Sheffield } \\
\text { Bristol }\end{array}$ & $\begin{array}{l}16 \\
11\end{array}$ & $\begin{array}{l}46 \\
58\end{array}$ & $\begin{array}{l}2 \\
2 \\
\end{array}$ & $\begin{array}{l}1 \\
0\end{array}$ & $\begin{array}{c}65 \\
71\end{array}$ \\
\hline & Total & $27(19 \cdot 9 \%)$ & $104(76 \cdot 5 \%)$ & $4(2 \cdot 9 \%)$ & $1(0.7 \%)$ & 136 \\
\hline
\end{tabular}


have been treated as firm values, i.e. free from statistical error due to paucity of cases.

(2) The standard errors of the other two figures have been assessed from the binomial distribution, taking the birth of a pair of twins as a single random event.

As a preliminary, the mutual compatibility of the Bristol and Sheffield figures in Table 1 was examined by means of $\chi^{2}$ tests $(3 \mathrm{D}$. of $\mathrm{F}$.) for each of the three conditions. The values were 9.03 (cerebral palsy), $3 \cdot 23$ (simple mental deficiency), $2 \cdot 24$ (mongol idiots); of these the first was significant, on the $5 \%$ level only, the other two being not significant. The significance was mainly due to the somewhat smaller percentage of full term twins in the Bristol figures, and was not considered important enough to prevent the two sets of figures being lumped together for further analysis.

TABLE 3

PROBABILITIES OF PREMATURITY AND MULTIPLICITY FROM DATA IN TABLE 2

\begin{tabular}{l|c}
\hline & $\begin{array}{c}\text { Estimated Probability } \\
(\%)\end{array}$ \\
\hline Premature singleton & $5 \cdot 28$ \\
Full-term singleton & $93 \cdot 47$ \\
Premature twin & $0 \cdot 72$ \\
Full-term twin & $0 \cdot 53$ \\
\hline Total & $100 \cdot 00$ \\
\hline
\end{tabular}

Note.-The second decimal is given to avoid accumulation of rounding off errors in working.

Since the incidence of twins is small, the number falling into any given category can be taken as a Poisson variate, provided that only one of a pair of siblings is included in the count. Also since Poisson variates are additive, results for premature and full term children may be added for the purpose of a test of significance. These two considerations lead
TABLE 4

OBSERVED AND EXPECTED INCIDENCE OF TWINS FOR DIFFERENT CONDITIONS

\begin{tabular}{|c|c|c|c|}
\hline & $\begin{array}{l}\text { Observed } \\
\text { Number }\end{array}$ & $\begin{array}{l}\text { Expected } \\
\text { Number }\end{array}$ & $\begin{array}{c}\text { Significance } \\
\text { of } \\
\text { Discrepancy }\end{array}$ \\
\hline $\begin{array}{l}\text { Cerebral palsy } \\
\text { Simple mental defectives } \\
\text { Mongol idiots }\end{array}$ & $\int_{4}^{54} 24$ & $\left.\begin{array}{l}30 \cdot 3 \\
17 \cdot 2 \\
4 \cdot 2\end{array}\right\} 21 \cdot 4$ & $\begin{array}{l}0.1 \% \text { level } \\
\text { Not signi- } \\
\text { ficant even } \\
\text { on } 5 \% \text { level }\end{array}$ \\
\hline
\end{tabular}

to Table 4 , the significance of the discrepancies being assessed by reference to the Poisson tables; the expected numbers are deduced by applying the incidence rates of Table 3 to the numbers of premature and full term cases at risk in the various categories. No allowance has been made for statistical errors in the expected numbers arising in their derivation from the data in Table 2 , and thus will tend to lead to a slight overstatement of the level of significance; notwithstanding this, the results are clear enough for there to be no doubt of the significantly greater incidence of twins among cases of cerebral palsy. On the other hand, there is no evidence of an abnormal incidence of twins in the presence of either of the other conditions.

\section{REFERENCES}

Asher, P. and Schonell, F. E. (1950). A survey of 400 cases of cerebral palsy in childhood. Arch. Dis. Childh., 25, 360.

Drillien, C. M. (1959). A longitudinal study of the growth and development of prematurely and maturely born children. Ibid., 34, 37

Greenspan, L. and Deaver G. G. (1953). Clinical approach to the etiology of cerebral palsy. Arch. phys. Med., 34, 478.

Illingworth, R. S. (1958). Recent Advances in Cerebral Palsy. Churchill, London.

Looft, C. (1931). L'évolution de l'intelligence des jumeaux. Acta paediat. (Uppsala), 12, 41.

McKinney, L Dunphy, D. and Pessin, V. (1958) A comparative study of 26 sets of multiple births. Amer. $J$. Dis. Child. 96, 624 .

Rosanoff, A. J. and Inman-Kane, C. V. (1933). Relation of premature birth and under-weight condition at birth to mental deficiency. Amer. J. Psychiat., 13 (o.s. 90), 829.

Yue, Shyh-Jong (1955). Multiple births in cerebral palsy. Amer. J. phys. Med., 34, 335 . 